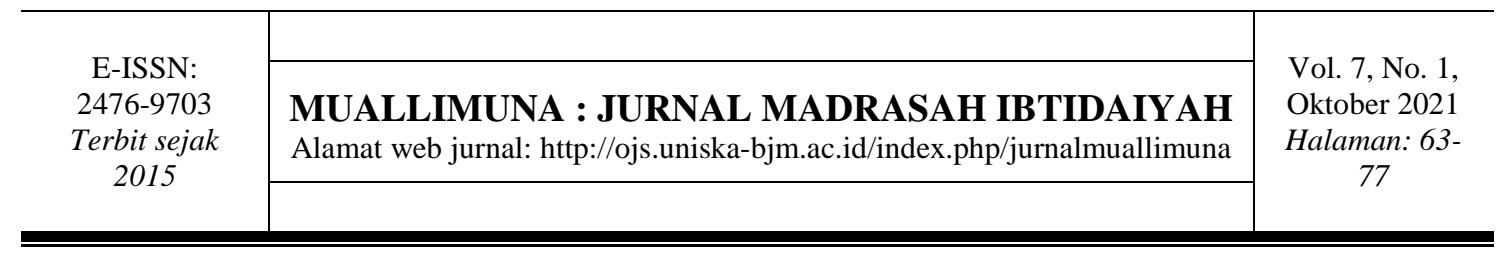

\title{
IMPLEMENTASI BUDAYA SEKOLAH BERWAWASAN LINGKUNGAN DALAM MEMBENTUK KARAKTER PEDULI LINGKUNGAN SISWA SEKOLAH DASAR
}

\author{
Ummi Nur Rokhmah ${ }^{1}$, Misbahul Munir ${ }^{2}$ \\ ${ }^{1}$ IAIN Syekh Nurjati Cirebon, ${ }^{2}$ STAI Ma'had Aly Al-Hikam Malang \\ umminurrokhmah@syekhnurjati.ac.id, ${ }^{2}$ misbah@staima-alhikam.ac.id
}

\begin{abstract}
Abstrak : Penelitian ini bertujuan untuk mendeskripsikan bagaimana implementasi budaya sekolah berwawasan lingkungan dalam membentuk karakter peduli lingkungan siswa di SDN temas 01 Batu. Penelitian ini menggunakan pendekatan kualitatif dengan jenis penelitian deskriptif. Penelitian dilakukan di SDN Temas 01 Batu dengan subjek penelitiannya adalah kepala sekolah, 3 guru, 4 siswa, 1 petugas kebersihan, 1 penjaga kantin dan orang tua siswa. Data dikumpulkan melalui teknik wawancara, observasi dan dokumentasi. Analisis data dilakukan melalui 3 tahap yaitu reduksi data, penyajian data dan penarikan kesimpulan. Keabasahan data diuji dengan menggunakan triangulasi sumber dan triangulasi teknik. Hasil penelitian menunjukkan bahwa budaya sekolah berwawasan lingkungan dimplementasikan melalui 3 langkah yaitu perencanaan, pelaksanaan dan evaluasi. Kegiatan perencanaan adalah membentuk tim pengelolaan lingkungan sekolah, membuat kajian lingkungan dan merencanakan aksi lingkungan. Kegiatan yang dilakukan saat pelaksanaan adalah membuat kebijakan berwawasan lingkungan, melaksanakan kurikulum berbasis lingkungan, melakukan kegiatan lingkungan berbasis partisipatif, dan mengelola sarana pendukung ramah lingkungan. Keberhasilan pelaksanaan dievaluasi dengan melakukan pemantauan terhadap keadaan keanekaragaman hayati di sekolah, tagihan listrik dan pengeluaran pembelian alat tulis kantor, menimbang jumlah sampah dan memantau kemampuan siswa dalam mengelola lingkungan dilihat dari aspek kognitif, afektif dan psikomotorik. Faktor pendukung yang mempengaruhi implementasi budaya sekolah berwawasan lingkungan adalah lokasi sekolah yang berada di lokasi yang masih asri dan mendapat banyak dukungan dari pihak luar. Sedangkan faktor penghambatnya adalah keterbatasan anggaran, masih terdapat siswa yang kurang memiliki kesadaran dalam memilah sampah dan masih terdapat banyak sampah plastik di sekolah.
\end{abstract}

Kata kunci : Budaya sekolah, lingkungan, Karakter, Peduli Lingkungan

\section{IMPLEMENTATION OF ENVIRONMENTAL SCHOOL CULTURE FOR SHAPING CHARACTER ENVIRONMENTAL CARE STUDENTS AT ELEMENTARY SCHOOL}

Abstract: The purpose of this study is describe implementation of environmental school culture for shaping character environmental care students at SDN Temas 01 Batu. This study used a qualitative approach with descriptive research. The study is conducted in SDN Temas 01 Batu with the subject of his research is the principal, 3 teachers, 4 
students, 1 janitor, 1 cafeteria guard and 2 parents of students. Data is collected through interview, observation, and documentation. Data analysis is carried out through 3 stages, datareduction, data display and verification. The validity of the information is tested by triangulation of techniques and triangulation of sources. The research results show that environmental school culture is implemented through 3 steps, planning, implementation and evaluation. Planning activities are forming school environmental management team, making environmental studies and planning environmental actions. Activities carried out during implementation are make environmental policies, implement environmental based curricula, conduct participatory based environmental activities, and manage environmental supporting facilities. The success of the implementation is evaluated by monitoring the state of biodiversity in schools, electricity bills and spending on purchasing office stationery, weighing the amount of waste and monitoring students' ability to manage the environment in terms of cognitive, affective and psychomotor aspects. The supporting factor that influences the implementation of an environmental school culture is the location of the school which is in a location that is still beautiful and gets a lot of support from outside parties. While the inhibiting factor is limitation of budget, there are still students who lack awareness in sorting waste and there is still a lot of plastic waste in schools.

\section{Keyword : School Culture, Environmental, Character, Environmental Care}

\section{PENDAHULUAN}

Permasalahan lingkungan hidup yang saat ini sering terjadi salah satu penyebab adalah karena ulah manusia sendiri. Permasalahaan yang sering timbul akibat ulah manusia antara lain yaitu eksploitasi sumber daya alam yang berlebihan dan penebangan pohon secara liar yang menyebabkan banjir ataupun tanah longsor. Pembuangan sampah di sembarang tempat, terlebih aliran sungai dan laut juga dapat melimbulkan pencemaran sehingga menimbulkan berbagai penyakit. Jika sikap manusia yang seringkali melakukan perusakan terhadap lingkungan belum berubah, maka bencana alam akan terus terjadi (Rokhmah, 2019).

Salah satu cara untuk mengatasi permasalahan lingkungan yang diakibatkan oleh manusia adalah dengan mengembangkan karakter peduli lingkungan kepada semua orang (Priambodo, Aslamiah, \& Rizalie, 2021). Untuk membentuk karakter peduli terhadap lingkungan dapat dilakukan melalui pendidikan (Tresnani, 2020).

Pendidikan adalah salah satu sarana yang digunakan untuk menerapkan dan membudayakan nilai-nilai budaya. Pendidikan berbasis budaya menjadi sebuah gerakan untuk menyadarkan masyarakat agar terus belajar mengatasi segala tantangan kehidupan yang semakin berat (Zafi, 2018).

Sekolah merupakan bentuk organisasi yang memiliki fokus pada permasalahan pendidikan. Budaya yang diterapkan di sekolah dapat menjadikan sekolah memiliki ciri khas tersendiri dalam melaksanakan kegiatan pembelajaran. Seharusnya sekolah memiliki lingkungan yang mendukung dalam melaksanakan kegiatan pembelajaran. Untuk mencapai hal tersebut, maka sekolah harus mempunyai budaya yang dapat memberikan dampak positif bagi seluruh warga sekolah. Budaya sekolah dapat menjadi sebuah pembeda antara sekolah satu dengan sekolah lain (Permana \& Ulfatin, 2018).

Pada 21 Februari 2006, Kementerian Lingkungan Hidup dan Kementerian Pendidikan Nasional mencanangkan budaya sekolah yang berwawasan lingkungan 
melalui program adiwiyata (Isnaeni, 2013). Berdasarkan Peraturan Lingkungan (Permen) Nomor 5 Tahun 2013 tentang Pedoman Pelaksanaan Program Adiwiyata, program adiwiyata bertujuan untuk mewujudkan sekolah yang peduli dan berbudaya lingkungan, pelaksanaannya adalah berlandaskan pada tiga prinsip yaitu edukatif, partisipatif, dan berkelanjutan (Juraid, Hamzah, Mahpudz, \& Khaldun, 2019). Program adiwiyata merupakan langkah untuk mewujudkan sekolah yang memiliki komitmen mendidik siswa yang peduli dan berbudaya lingkungan (Fadlilah, Ngabekti, \& Lis diana, 2018).

Budaya sekolah berwawasan lingkungan melalui program adiwiyata membawa dampak yang baik bagi dunia pendidikan, dimana intensitas keterlibatan siswa dalam kegiatan lingkungan akan mempengaruhi kepribadian, bentuk tanggung jawab perilaku, serta memiliki cara pandang dan kemampuan manajemen yang baik (Nada, Fajarningsih, \& Astirin, 2021). Budaya sekolah berwawasan lingkungan melalui program adiwiyata menyediakan sumber belajar yang dapat membantu siswa untuk mendapatkan ilmu pengetahuan khususnya pada materi bertema lingkungan. Keadaan sekolah yang rutin melaksanakan pembiasaan pada siswanya untuk peduli terhadap lingkungan, dapat membantu pembentukan karakter peduli lingkungan. Karakter seseorang harus dikembangkan melalui 3 tahap yaitu pengetahuan, pelaksanaan, dan kebiasaan (Aini, Rachmadiarti, \& Prastiwi, 2014).

Karakter peduli lingkungan adalah salah satu karakter yang wajib diimplementasikan di sekolah pada setiap jenjang pendidikan. Seluruh warga sekolah harus memiliki kesadaran tentang pentingnya menjaga lingkungan serta mempunyai inisiatif untuk mencegah kerusakan lingkungan (Purwanti, 2017). Sejak dini pembentukan karakter peduli terhadap lingkungan harus diberikan kepada siswa agar mereka memiliki kearifan dalam mengelola sumber daya alam di sekitarnya, juga memiliki rasa tanggung jawab terhadap kepentingan generasi penerus (Masturoh \& Ridlo, 2020). Jika karakter peduli lingkungan dapat diwujudkan dalam sebuah tindakan, siswa akan selalu peduli terhadap lingkungan dan melestarikannya dengan sepenuh hati, baik di sekolah maupun di tempat tinggalnya (Fatimah \& Adawiyah, 2017).

Salah satu sekolah yang telah menerapkan budaya sekolah berwawasan lingkungan melalui program adiwiyata adalah SDN Temas 01 Batu. SDN Temas 01 Batu telah mendapat penghargaan sebagai sekolah adiwiyata nasional pada tahun 2014. Suasana di lingkungan sekolah sangat asri. Hal ini dikarenakan banyaknya tumbuhan hijau yang ditanam di taman sekolah dan di lingkungan sekitar sekolah. Seluruh warga SDN Temas 01 Batu juga mempunyai wawasan lingkungan yang baik. Terbukti dari keadaan lingkungan sekolah yang rapi, bersih, dan tidak ada sampah yang berserakan.

Dari beberapa uraian diatas, maka peneliti melakukan penelitian yang bertujuan untuk mendeskripsikan bagaimana perencanaan, pelaksanaan dan evaluasi budaya sekolah berwawasan lingkungan di SDN Temas 01 Batu. Selain itu penelitian ini juga mendeskripsikan apa saja faktor yang dapat mempengaruhi implementasi budaya sekolah berwawasan lingkungan di SDN Temas 01 Batu baik faktor pendukung maupun faktor penghambat serta apa saja upaya yang telah dilakukan oleh pihak sekolah dalam mengatasi hambatan-hambatan yang ada.

\section{METODE}

Penelitian ini menggunakan pendekatan kualitatif dengan jenis penelitian deskriptif. Penelitian deskriptif ditujukan untuk mendeskripsikan suatu keadaan atau fenomenafenomena apa adanya tanpa melakukan manipulasi ataupun memberikan perlakuan- 
perlakuan tertentu terhadap objek penelitian, semua kegiatan atau peristiwa berjalan seperti apa adanya (Sukmadita, 2013). Lokasi penelitian berada di SDN Temas 01 Batu, sedangkan yang menjadi subjek penelitian adalah kepala SDN Temas 01 Batu, 3 guru, 4 siswa, 1 petugas kebersihan, 1 penjaga kantin dan 2 orang tua siswa. Data dikumpulkan melalui teknik wawancara mendalam, observasi non partisipan, dan dokumentasi. Analisis data dilakukan melalui tiga tahapan yaitu reduksi data, penyajian data dan penarikan kesimpulan. Adapun reduksi data dilakukan untuk menemukan data yang sama atau relevan sebagai acuan peneliti. Sedangkan penyajian data diperoleh dalam bentuk paragraf singkat yang di sajikan dalam bentuk naratif (dengan teks). Penarikan kesimpulan yaitu memberikan penjelasan dan menarik kesimpulan dari penelitian yang ada berdasarkan hasil wawancara, observasi dan di dukung dengan dokumen (Miles, Huberman, \& Saldana, 2014). Keabsahan data diuji menggunakan triangulasi sumber dan triangulasi teknik.

\section{HASIL DAN PEMBAHASAN}

\section{Hasil}

Berdasarkan hasil wawancara, observasi dan dokumentasi ditemukan bahwa budaya sekolah berwawasan lingkungan dalam membentuk karakter peduli lingkungan siswa di SDN Temas 01 Batu diimplementasikan melalui 3 langkah yaitu perencanaan, pelaksanaan dan evaluasi.

1. Perencanaan Budaya Sekolah Berwawasan Lingkungan dalam Membentuk Karakter Peduli Lingkungan Siswa SDN Temas 01 Batu

Perencanaan awal yang dilakukan sebelum pelaksanaan budaya sekolah berwawasan lingkungan di SDN temas 01 Batu adalah membentuk tim yang khusus menangani pengelolaan dan pelestarian lingkungan di sekolah. Tim ini disebut dengan tim adiwiyata sekolah. Tim adiwiyata sekolah ini beranggotakan semua warga sekolah dan juga komite sekolah. Agar program adiwiyata terlaksana dengan maksimal, tim adiwiyata sekolah membuat 4 kelompok kerja (pokja) yaitu pokja kebijakan, pokja kurikulum, pokja partisipatif, dan pokja sarpras. Siswa dilibatkan pada pokja partisipatif dan pokja sarpras.

Setelah membentuk tim, tahap selanjutnya yaitu merancang kajian lingkungan sekolah. Kajian lingkungan memuat tentang permasalahan lingkungan yang ada di sekolah meliputi permasalah sampah, energi, air, kantin sekolah, dan keanekaragaman hayati di sekolah. Analisis kajian lingkungan dibuat oleh tim adiwiyata sekolah dan melibatkan seluruh siswa SDN Temas 01 Batu. Analisis kajian lingkungan dibuat untuk merencanakan aksi lingkungan Aksi lingkungan dilakukan untuk menangani permasalahan lingkungan yang ada di SDN Temas 01 Batu. Rencana aksi dibuat disesuaikan dengan 4 komponen dalam pelaksanaan program adiwiyata yaitu kebijakan berwawasan lingkungan, pelaksanaan kurikulum, kegiatan berbasis partisipatif dan pengelolaan sarana ramah lingkungan. SDN Temas $01 \mathrm{Batu}$ menyiapkan anggaran sebesar $20 \%$ untuk aksi-aksi lingkungan sebagai perwujudan dari budaya sekolah yang berwawasan lingkungan.

2. Pelaksanaan Budaya Sekolah Berwawasan Lingkungan dalam Membentuk Karakter Peduli Lingkungan Siswa SDN Temas 01 Batu

Budaya sekolah berwawasan lingkungan di SDN Temas 01 Batu dilaksanakan oleh tim Adiwiyata dengan menerapkan 4 komponen dalam program adiwiyata. 
a. Membuat Kebijakan Berwawasan Lingkungan

Salah satu kebijakan berwawasan lingkungan di SDN Temas Batu 01 adalah merancang visi, misi dan tujuan sekolah yang memuat tentang perlindungan dan pengelolaan lingkungan hidup. Hal tersebut dilakukan agar siswa ikut serta mewujudkan perlindungan dan pengelolaan lingkungan hidup seperti pada visi misi dan tujuan sekolah. Visi dan misi sekolah dipasang di setiap ruang agar seluruh warga sekolah khususnya siswa dapat dengan mudah menghafal visi dan misi sekolah. Dengan hafalnya visi dan misi sekolah tersebut, maka siswa akan lebih semangat untuk mewujudkan visi dan misi sekolah. SDN Temas 01 Batu juga membuat lagu tentang visi sekolah yang dinyanyikan selesai upacara dan sebelum siswa masuk kelas pada jam pertama.

SDN Temas 01 Batu membuat beberapa kebijakan tentang pelaksanaan pendidikan lingkungan hidup (PLH) dalam pembelajaran. Kebijakan tersebut menjelaskan bahwa pendidikan lingkungan hidup (PLH) di SDN Temas 01 Batu diajarkan secara monolitik dan terintegrasi pada semua mata pelajaran yang dapat diintegrasi dengan tema lingkungan. Selain terintegrasi dalam pembelajaran, PLH juga diintegrasikan pada kegiatan ekstrakuliler dan kegiatan rutin sehari-sehari siswa seperti kegiatan jumat bersih dan kegiatan membersihkan kelas sebelum dan sesudah pembelajaran.

SDN Temas 01 Batu juga membuat peraturan sekolah berbasis lingkungan sebagai upaya perlindungan dan pengelolaan lingkungan sekolah. Peraturan yang pertama adalah peraturan yang mewajibkan seluruh warga sekolah untuk selalu menjaga kebersihan lingkungan sekolah dengan membuang sampah pada tempatnya. Tempat sampah berwarna biru untuk sampah organik atau tumbuhtumbuhan dan tempat sampah berwarna kuning untuk sampah non organik atau selain tumbuh-tumbuhan. Peraturan yang kedua yaitu peraturan untuk melestarikan keanekaragaman hayati di sekolah dengan cara merawat taman sekolah. Peraturan ketiga adalah peraturan untuk menghemat energi listrik dan air jika tidak terpakai. Peraturan yang keempat yaitu peraturan yang mewajibkan pengelola kantin untuk menjual makanan yang sehat dan tidak mengandung zatzat berbahaya. Agar memudahkan siswa mengingat peraturan yang telah dibuat, maka guru membuat kalimat ajakan dan slogan bertema lingkungan yang diletakkan di seluruh kelas, baik di dalam maupun di luar kelas.
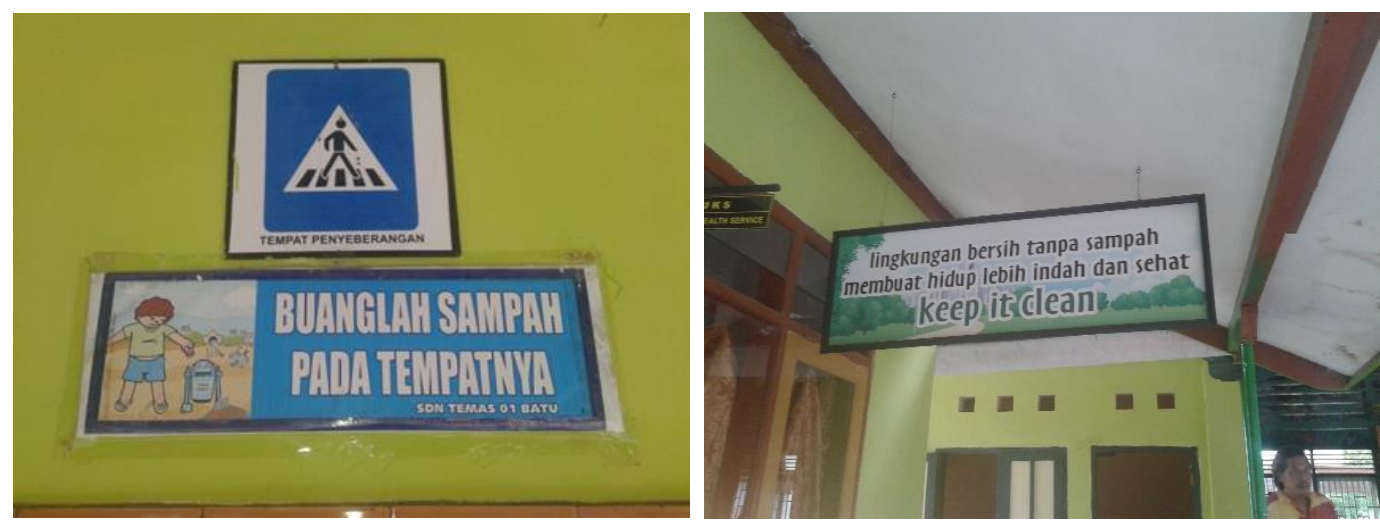

Gambar 1. Kata ajakan dan slogan bertema lingkungan

b. Melaksanakan Kurikulum Berbasis Lingkungan 
SDN Temas 01 Batu menggunakan kurikulum 2013 (K13) yang diintegrasikan dengan kurikulum yang berbasis lingkungan pada program adiwiyata. Dalam kurikulum berbasis lingkungan, pendidikan lingkungan hidup (PLH) diajarkan secara monolitik maupun secara integratif. Pembelajaran PLH secara monolitik yaitu dengan menjadikan PLH sebagai mata pelajaran muatan lokal yang berdiri sendiri untuk kelas 1-6. Pelajaran PLH diberi alokasi waktu sebanyak 2 jam pelajaran setiap minggu dan memiliki kriteria ketuntasan minimal (KKM) 75. PLH yang diajarkan secara integratif dilakukan dengan mengintegrasikan PLH pada setiap mata pelajaran wajib, muatan lokal dan pembelajaran tematik. namun tidak semua materi pokok pada mata pelejaran selain PLH dapat diintegrasikan dengan PLH. Rencana pelaksanaan pembelajaran (RPP) pada materi pokok yang dapat diintegrasi dengan PLH telah memuat indikator ketuntasan pendidikan lingkungan hidup.

Penyampaian materi yang berkaitan dengan lingkungan baik pada mata pelajaran PLH atau mata pelajaran lain yang terintegrasi PLH, guru menggunakan strategi, dan metode pembelajaran yang bervariasi dan melibatkan siswa secara aktif terlibat dalam pembelajaran (student centered). Strategi pembelajaran yang sering digunakan adalah CTL dan SPI, sedangkan metode pembelajaran yang sering digunakan adalah metode observasi, diskusi, demontrasi, praktek langsung dan penugasan. Kegiatan pembelajaran dilaksanakan di dalam kelas dan dilaksanakan di luar kelas. Hal ini dilakukan agar siswa lebih semangat dan tidak bosan dalam belajar. Selain itu siswa dapat bersentuhan langsung dengan alam. Guru juga memasukkan isu-isu tentang lingkungan, baik isu lokal maupun isu global pada materi ajar mata pelajaran PLH dan mata pelajaran lain yang terintegrasi dengan PLH agar memudahkan siswa memahami materi.

Pada pembelajaran PLH, guru mengajarkan siswa membuat karya-karya bertema lingkungan seperti kerajinan yang terbuat dari bahan bekas dan karya ilmiah yang berkaitan dengan lingkungan. Hasil karya siswa dari kegiatan pembelajaran diletakkan di dalam dan di luar kelas, agar semua warga sekolah khususnya siswa dapat melihat karya-karya yang telah dibuat. Guru juga melibatkan orang tua siswa dalam pembelajaran lingkungan hidup. Orang tua siswa dilibatkan dalam pemberikan keteladanan perilaku peduli lingkungan di rumah. Penilaian sikap siswa tidak hanya dilakukan saat jam pelajaran berlangsung, melainkan dilakukan di luar jam pelajaran dengan cara melihat sikap kepedulian siswa terhadap lingkungan saat di luar jam pelajaran. Dalam mengamati sikap siswa tersebut, guru dibantu oleh guru lain dan siswa yang menjadi polisi lingkungan.

Pendidikan lingkungan hidup juga diintegrasikan pada beberapa kegiatan ekstrakurikuler yang ada di sekolah dengan cara menyisipkan tema lingkungan pada kegiatannya. Contoh ekstrakulikuler yang dapat diintegrasikan yaitu pramuka dan dokter kecil. SDN Temas 01 juga membuat ekstrakurikuler yang kegiatan utamanya adalah melakukan pengelolaan dan perlindungan terhadap lingkungan sekolah. Ekstrakurikuler tersebut dinamakan dengan CLING (cinta lingkungan). Sebelum dan sesudah kegiatan ekstrakulikuler, siswa selau dibiasakan untuk membersihkan dan merapikan tempat kegiatan ekstrakuliler.

c. Melaksanakan Kegiatan Lingkungan Berbasis Partisipatif

Kegiatan pengelolaan dan perlindungan lingkungan sekolah dilakukan melalui kegiatan rutin harian dan juga kegiatan tahunan. Kegiatan yang dilakukan 
rutin setiap pagi adalah membersihkan kelas dan halaman sekolah. Kegiatan membersihkan kelas dilakukan oleh siswa pada masing-masing kelas sedangkan kegiatan membersihkan halaman sekolah hanya dilakukan oleh siswa kelas IV dan $\mathrm{V}$ dan dilakukan secara berurutan dimulai dari hari senin kelas IV a, selasa IV b, rabu IV c, kamis V a, jumat V b dan Sabtu V c. Kegiatan lingkungan yang rutin dilakukan setiap 1 minggu sekali adalah kegiatan jumat bersih. Kegiatan jumat bersih dilakukan oleh semua warga sekolah dan dibantu oleh orang tua siswa secara bergantian.
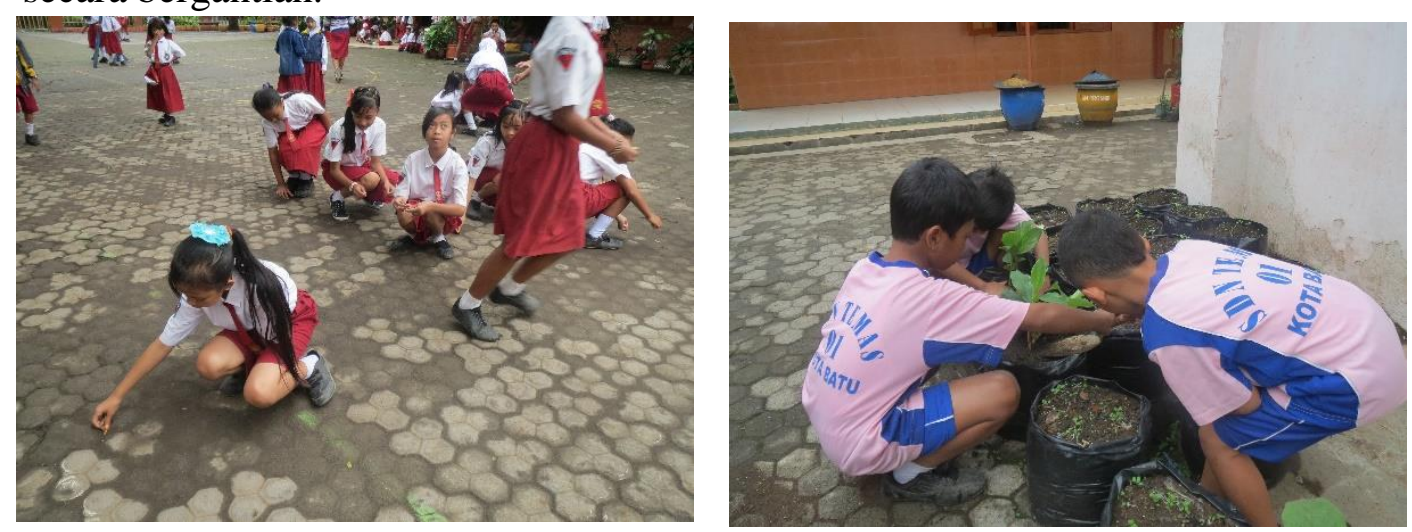

Gambar 2. Siswa membersihkan halaman sekolah dan menanam tanaman dalam kegiatan jumat bersih

Kegiatan rutin tahunan yang dilakukan di SDN temas 01 Batu disebut dengan hari Aksi. Kegiatan ini dilakukan di lingkungan sekolah maupun di luar lingkungan sekolah pada hari-hari besar yang berkaitan dengan lingkungan hidup seperti hari sampah dan hari air. Kegiatan yang dilakukan dalam rangka memperingati hari sampah adalah membersihkan terminal kota Batu bekerjasama dengan kecamatan kota Batu. Dalam rangka memperingati hari sampah juga semua warga sekolah mengadakan kegiatan bersih-bersih lingkungan kelurahan Temas dengan bekerjasama dengan Kelurahan Temas. Kegiatan yang dilakukan dalam rangka memperingati hari air adalah membagikan stiker hemat air kepada warga yang melintasi SDN Temas 01 Batu. Dalam memperingati hari-hari besar yang berkaitan dengan lingkungan hidup, sekolah juga mengadakan lomba yang berkaitan dengan lingkungan. Lomba yang pernah dilaksanakan di SDN Temas 01 Batu adalah lomba kebersihan kelas dan lomba mendaur ulang sampah non organik pada hari sampah serta lomba membuat puisi dan gambar tentang air pada hari air.

d. Mengelola Sarana dan Prasarana Pendukung Ramah Lingkungan

Pengelolaan sarana pendukung ramah lingkungan dalam membentuk karakter peduli lingkungan siswa di SDN Temas 01 Batu yaitu menyediakan sarana prasarana untuk mengatasi permasalahan lingkungan di sekolah. Sarana dan prasarana yang telah disediakan SDN Temas 01 Batu untuk mengatasi masalah-masalah lingkungan di sekolah adalah:

1) Tempat sampah terpilah. Warna kuning untuk non organik dan biru untuk sampah organik.

2) Alat-alat kebersihan seperti sapu, pengki dan dan kemoceng.

3) Tempat cuci tangan/ wastafel dan toilet yang sediakan sebanding dengan jumlah siswa. 
4) Sumur resapan dan biopori untuk menampung buangan air limbah dan air hujan.

5) Mesin komposter untuk membuat pupuk kompos dari sampah organik.

6) Tandon air untuk mengurangi tekanan air yang terlalu besar agar kran tidak mudah rusak.

7) Kantin yang ramah lingkungan dan menyediakan makanan sehat.

SDN Temas 01 Batu juga menyediakan sarana prasarana yang digunakan untuk pembelajaran lingkungan hidup. Sarana dan prasarana yang digunakan SDN Temas 01 Batu untuk pembelajaran lingkungan hidup antara lain adalah taman toga, green house, dan kolam ikan untuk pembelajaran keanekaragaman hayati, mesin komposter untuk pembelajaran membuat pupuk kompos dari sampah organik. biopori dan sumur resapan untuk pembelajaran pengelolaan air limbah dan air hujan.
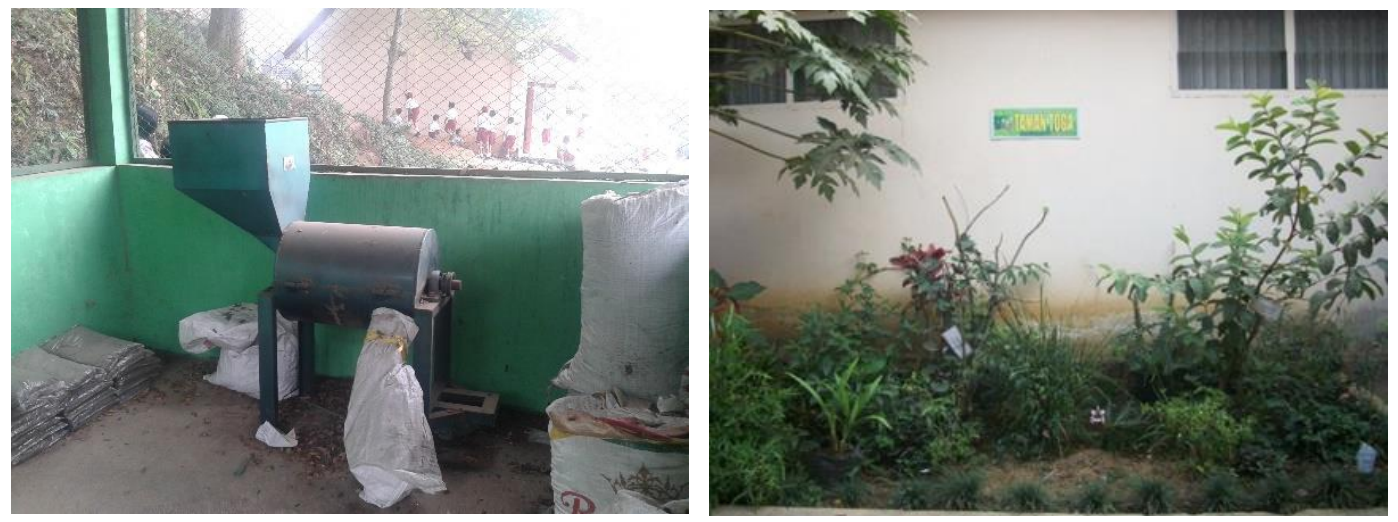

Gambar 3. Sarana dan prasarana yang digunakan untuk pembelajaran membuat pupuk kompos dan mengenal keanekaragaman hayati

SDN Temas 01 Batu secara rutin melakukan perawatan sarana dan prasarana ramah lingkungan agar dapat berfungsi dengan baik. Perawatan yang rutin dilakukan yaitu selalu membersihkan fasilitas sanitasi sekolah seperti toilet dan wastafel. Selain itu juga selalu membersihkan sampah di tempat sampah. Jika sampah sudah penuh maka dibuang ke pembuangan sampah sementara sesuai dengan jenisnya. Selain itu fasilitas sanitasi sekolah seperti toilet dan wastafel juga selalu dibersihkan. Taman, green house dan kolam ikan juga selau rutin dirawat dan dibersihkan. Selalu melakukan mengecekan rutin terhadap fungsi biopori dan sumur resapan yang ada di sekolah. Kantin sekolah selalu dipantau agar makanan yang dijual sehat dan bersih.

3. Evaluasi Budaya Sekolah Berwawasan Lingkungan dalam Membentuk Karakter Peduli Lingkungan Siswa SDN Temas 01 Batu

Evaluasi ketercapaian pelaksanaan budaya sekolah yang berwawasan lingkungan dilaksanakan oleh tim adiwiyata sekolah dengan cara melakukan pemantauan setiap bulan selama satu tahun. Untuk melihat keberhasilan pengelolaan lingkungan sekolah, tim adiwiyata melakukan dokumentasi berupa catatan dan foto keadaan lingkungan di sekolah. Tim adiwiyata melakukan pencatatan jenis dan jumlah tanaman maupun ikan yang ada di taman sekolah, taman toga, greenhouse $d$ an kolam ikan. Dokumentasi dilakukan setiap bulan untuk melihat perkembangan keberhasilan pelestarian keanekaragaman hayati di sekolah. Untuk menilai tingkat efisiensi penggunaan air, listrik dan alat tulis kantor (ATK), tim pengelola lingkungan sekolah melakukan pemantauan terhadap tagihan air, listrik dan 
pengeluaran sekolah untuk pembelian alat tulis kantor (ATK). Semakin sedikit biaya tagihan listrik dan pengeluaran untuk membeli ATK setiap bulannya membuktikan bahwa warga sekolah terutama siswa sudah memanfaatkan listrik, air dan ATK secara efisiensi.

Tim pengelola lingkungan sekolah secara rutin melakukan penimbangan terhadap sampah yang akan di daur ulang dan yang akan diubah fungsinya untuk mengetahui keberhasilan pengelolaan sampah. Setiap bulan sampah yang ada di sekolah ditimbang dan dicatat beratnya. Selanjutkan melakukan perbandingan terhadap jumlah sampah pada tiap bulannya. Semakin banyak jumlah sampah di daur ulang dan dirubah fungsinya menjadi barang yang lebih bermanfaat membuktikan bahwa budaya sekolah berwawasan lingkungan telah berhasil menangani permasalahan masalah sampah.

Tim pengelola lingkungan sekolah yang dibantu oleh semua guru juga melakukan evaluasi pada kemampuan siswa dilihat dari aspek pengetahuan, sikap dan ketrampilan siswa setelah melakukan pembelajaran dan kegiatan rutin terkait lingkungan. Untuk mengetahui tingkat pengetahuan siswa terhadap lingkungan, guru memantau nilai-nilai siswa mata pelajaran PLH dan mata pelajaran yang terintegrasi dengan lingkungan. Untuk memantau sikap siswa yang mencerminkan kepedulian terhadap lingkungan, guru mengamati perilaku siswa sehari-hari baik saat pembelajaran maupun di luar pembelajaran. Sedangkan untuk mengetahui ketrampilan siswa dalam menangani permasalahan lingkungan, guru menilai dari kemampuan siswa dalam menghasilkan karya bertemakan lingkungan seperti karya ilmiah bertema lingkungan, tas, pot bunga, gelas, tirai, dan kerajinan tangan, dan barang lain yang terbuat dari daur ulang sampah.

4. Faktor yang Mempengaruhi Pembentukan karakter peduli lingkungan melalui budaya sekolah berwawasan lingkungan.

Terlaksanakanya budaya sekolah berwawasan lingkungan dipengaruhi oleh faktor pendukung dan juga faktor penghambat. Faktor pendukung kelancaran dan keberhasilan implementasi buadaya sekolah berwawasan lingkungan di SDN Temas 01 Batu adalah lokasi sekolah berada di kawasan yang masih asri dan jauh dari pabrik yang menimbulkan polusi udara. Faktor pendukung yang kedua yaitu banyaknya dukungan dari pihak luar kepada sekolah untuk melaksanakan budaya sekolah berwawasan lingkungan. Berbagai pihak yang membantu pelaksanaan budaya sekolah berwawasan lingkungan adalah antara lain:

1) Kelurahan Temas memberikan dukungan berupa penyediaan bibit sayuran dan buah-buahan serta membantu dalam kegiatan membersihkan lingkungan sekitar sekolah ketika ada kegiatan besar di sekolah

2) CV Bunga Melati Batu memberikan dukungan berupa penyediaan tanaman hias serta membantu dalam pembuatan dan pengelolaan taman yang indah.

3) Kementrian pertanian kota Batu membantu dalam mengajarkan cara pembuatan pupuk kompos.

4) Kementrian kesehatan membantu dalam pengelolaaan kantin sehat.

5) Kementrian lingkungan hidup dan kehutanan kota Batu memberikan dukungan berupa pengadaan tempat sampah terpilah.

6) Orang tua siswa memberikan dukungan berupa penyediaan tanaman toga dan tanaman hias serta membantu dalam kegiatan jumat bersih setiap hari jumat dan pembagian makanan sehat. 
7) Masyarakat sekitar membantu dalam kegiatan membersihkan lingkungan sekitar sekolah jika ada kegiatan besar di sekolah.

Faktor penghambat implementasi budaya sekolah berwawasan lingkungan yaitu masih terbatasnya anggaran yang dapat dialokasikan untuk penyediaan sarana prasarana ramah lingkungan di sekolah. Hambatan lain yaitu masih terdapat siswa yang memiliki kesadaran kurang baik dalam memilah sampah sehingga sampah organik dan non organik masih tercampur. Sampah yang tercampur antara sampah organik, dan non organik dapat menyulitkan proses daur ulang sampah.

Hambatan selanjutnya yaitu masih terdapat banyak sampah plastik di sekolah. Hal ini disebabkan karena masih terbatasnya jenis makanan yang dijual di kantin. Masih terdapat siswa yang lebih memilih membeli makanan di luar sekolah yang kebanyakan masih menggunakan plastik sebagai pembungkus makanan. Sampah plastik sulit untuk diurai oleh tanah, membutuhkan waktu antara 100 sampai 500 tahun. Banyaknya sampah plastik dapat menyebabkan tanah dan yang ada di dalamnya menjadi tercemar.

SDN Temas 01 Batu melakukan berbagai upaya dalam mengatasi hambatanhambatan yang ada. Upaya yang dilakukan diantaranya yaitu melakukan kerjasama dengan berbagai pihak agar dapat membantu terlaksananya budaya sekolah berwawasan ligkungan khususnya dalam penyediaan sarana prasarana ramah lingkungan di sekolah. Beberapa bantuan dari pihak luar sekolah yang pernah diberikan kepada sekolah yaitu bantuan dalam pengadaan tanaman hias, tanaman toga, bibit sayuran dan buah-buahan serta tempat sampah untuk sampah organik dan non organik.

Pihak sekolah juga melakukan kerjasama dengan orang tua siswa sebagai upaya membiasakan siswa membuang sampah pada tempatnya dan secara terpilah ketika berada di rumah. Sedangkan di sekolah, guru memberikan peringatan dan sanksi bagi siswa yang tidak membuang sampah pada tempatnya dan tidak secara terpilah agar siswa menjadi jera dan tidak mengulangi perbuatan. Sanksi yang diberikan untuk siswa yang membuang sampah tidak pada tempat yang telah disediakan dan tidak secara terpilah di sekolah adalah denda sebesar 500 rupiah per satu sampah.

Upaya lain dalam menanggulangi sampah plastik di sekolah yaitu dengan menerapkan $3 \mathrm{R}$ (Reduse, Reuse dan Recycle). Reduse yaitu tindakan meminimalisir penggunaan plastik untuk pembungkus makanan dengan cara memberikan sosialisasi kepada penjual di kantin maupun diluar sekolah untuk mengurangi penggunaan plastik sebagai pembungkus makanan dan memberikan sosialisasi kepada orang tua siswa untuk memperingatkan putra putrinya agar tidak membawa makanan yang berkemasan plastik ke sekolah. Reuse yaitu tindakan menggunakan bahan plastik secara berulang seperti penggunaan botol minum plastik, Recycle yaitu tindakan mendaur ulang sampah plastik yang masih bersih seperti botol minuman dan kemasan jajan bekas untuk dijadikan barang yang memiliki daya guna. Contoh Barang hasil daur ulang sampah plastik antara lain yaitu tas, gelas, pot bunga, tirai dan kerajinan tangan seperi bunga plastik. Untuk mengurangi sampah plastik, SDN Temas 01 Batu juga meminta bantuan pemulung untuk mengambil sampah plastik dan barang-barang bekas yang tidak terpakai. 

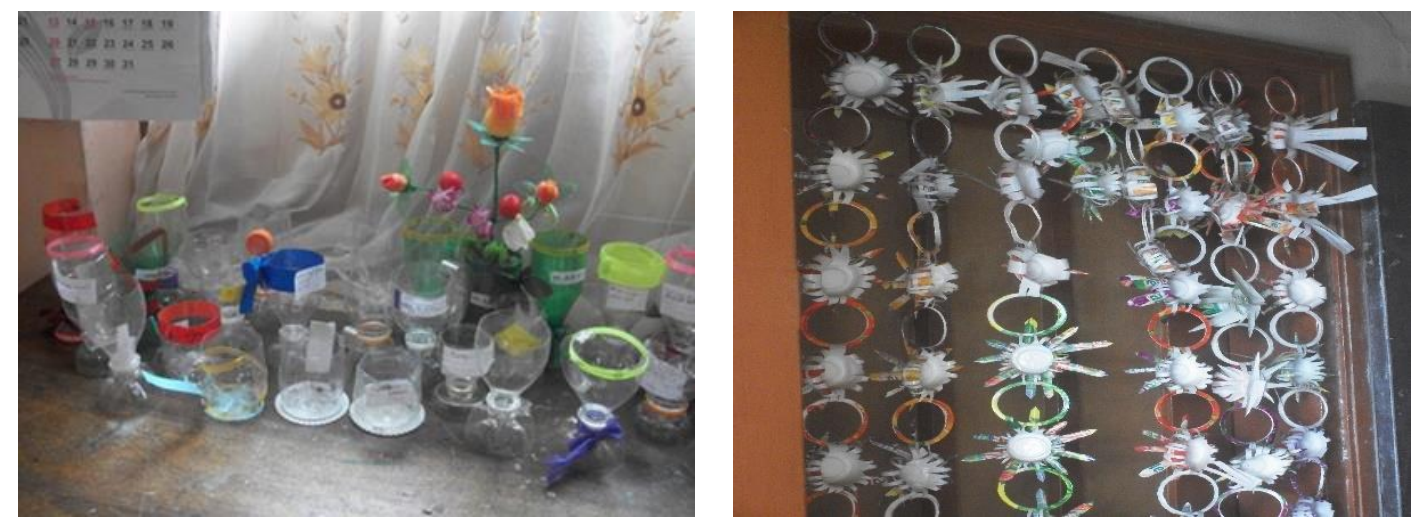

Gambar 4. Sampah plastik yang didaur ulang menjadi barang memiliki daya guna lebih seperti gelas, pot bunga dan tirai

\section{Pembahasan}

Pelaksanaan budaya sekolah yang berwawasan lingkungan melalui program adiwiyata dilakukan oleh tim adiwiyata sekolah yang melibatkan seluruh warga sekolah untuk peduli dengan lingkungan. Dalam pelaksanaanya harus sesuai dengan perencanaan yang telah ditetapkan sebelumnya oleh tim adiwiyata sekolah (Riki \& Sumarnie, 2021). Budaya sekolah berwawasan lingkungan diterapkan melalui empat komponen program adiwiyata yang menjadi satu kesatuan utuh sebagai upaya pembentukan karakter peduli lingkungan warga sekolah. Keempat komponen tersebut adalah membuat kebijakan berwawasan lingkungan, menerapkan kurikulum berbasis lingkungan, melaksanakan kegiatan lingkungan berbasis partisipatif dan mengelola sarana prasarana pendukung yang ramah lingkungan (Desfandi, Maryani, \& Disman, 2019).

Salah satu budaya sekolah berwawawan lingkungan melalui program adiwiyata adalah menerapkan kebijakan berwawasan lingkungan. Kebijakan berwawasan lingkungan diantaranya memasukkan tema lingkungan dalam visi, misi, dan tujuan sekolah, merancang berbagai program mata pelajaran dan pengembangan diri yang terintegrasi dengan adiwiyata, menyusun rencana kegiatan dan anggaran untuk adiwiyata sebesar $21 \%$ dari keseluruhan anggaran sekolah, menyediakan sarana dan prasarana untuk kebutuhan pelaksanaan program adiwiyata, mengadakan kegiatan kerja bakti membersihkan lingkungan sekolah, mengadakan kerjasama pengelolaan lingkungan dengan sekolah atau lembaga lain yang menangani pengelolaan dan perlindungan lingkungan hidup (Wardani, 2020).

Guru wajib memiliki kemampuan dalam mengembangkan strategi dan metode pembelajaran yang melibatkan siswa secara aktif dalam pembelajaran lingkungan hidup (Wardani, 2020). Materi pembelajaran yang terkandung dalam PLH sebagai mata pelajaran muatan lokal berkaitan dengan lingkungan seperti isu-isu yang meliputi ekosistem, degradasi lingkungan, energi dan limbah. Isu-isu terkait lingkungan juga diintegrasikan pada mata pelajaran wajib. Mengintegrasikan isu-isu lingkungan dalam pembelajaran ditujukan untuk memberikan pengetahuan dan membangun karakter peduli lingkungan pada siswa. Penilaian PLH sebagai hasil pembelajaran mata pelajaran muatan lokal dilaksanakan melalui proyek membuat kerajinan tangan dari berbagai 
bahan limbah. Penilaian hasil belajar PLH yang teritegrasi pada mata pelajaran wajib meliputi penjelasan, membuat puisi, dan tugas proyek bertema lingkungan. Kegiatan tersebut dapat mengukur kognitif, afektif dan psikomotorik, sehingga keterampilan siswa dapat dievaluasi secara komprehensif (Caddafie, Martuti, \& Rudyatmi, 2017).

Menciptakan lingkungan yang bersih membutuhkan partisipasi seluruh warga sekolah dimana melaksanakaan kegiatan berbasis lingkungan adalah suatu keharusan. Kegiatan lingkungan dapat dilakukan setiap hari dengan membuat jadwal setiap kelas secara bergantian merawat tanaman di sekolah, menyapu halaman, mengambil, dan membuang sampah pada tempatnya. Kegiatan lingkungan juga dapat dilaksanakan setiap satu minggu sekali dengan melibatkan seluruh warga sekolah. Kegiatan ini dilakukan untuk menjaga kebersihan lingkungan sekolah, seperti penanaman pohon, merawat taman sekolah, toga, dan membuat bank sampah. Sekolah juga dapat melakukan berbagai kegiatan pengelolaan lingkungan pada hari-hari bertema lingkungan seperti pada hari bumi, hari air, dan hari pohon dan juga berpartisipasi dalam berbagai kegiatan lingkungan yang diselenggarakan oleh pihak di luar sekolah (Adawiyah, 2019).

Sekolah perlu menyediakan sarana prasarana untuk mengatasi permasalahan lingkungan hidup dan sarana prasarana yang dapat mendukung pembelajaran lingkungan hidup. Contohnya seperti IPAL, green house, TOS (tanaman obat sekolah), lubang biopori, komposter dan sarana prasarana lainnya. Peningkatan kualitas pengelolaan sarana dan prasarana ramah lingkungan di sekolah, dilakukan dengan pemanfaatan dan pemeliharaan lingkungan sekolah yang melibatkan seluruh warga sekolah bahkan masyarakat dan orang tua/wali siswa (Pradini, Sujanto, \& Nurjannah, 2018).

Monitoring evaluasi budaya sekolah berwawasan lingkungan melalui program adiwiyata dilakukan oleh kepala sekolah selaku penanggung jawab dengan memantau setiap kegiatan yang sedang berjalan agar sesuai dengan rencana yang sudah ditentukan. Dengan melihat catatan hasil laporan kegiatan baik itu dokumentasi, wawancara, kuesioner maupun survei yang dilakukan oleh tim adiwiyata sekolah dari masingmasing kelompok kerja atau POKJA untuk di tindak lanjuti ketercapaian dari kegiatan tersebut. Evaluasi dilakukan setiap 1 bulan untuk memperbaiki keterlaksanaan program. Dalam praktiknya pengawasan juga dilakukan dengan melibatkan Dinas Lingkungan Hidup dan Puskesmas Samuda dalam penanganan kantin sehat. Kementerian Lingkungan Hidup (2013) menyatakan monitoring dan evaluasi dilakukan dengan tujuan untuk mengetahui apakah tim Adiwiyata sekolah berhasil mencapai target yang tercantum dalam rencana aksi lingkungan atau tidak, sehingga harus dilakukan pemantauan untuk mengukur kemajuan yang diharapkan (Riki \& Sumarnie, 2021).

Sekolah perlu menganalisis apa saja faktor pendukung maupun faktor penghambat yang dapat mempengaruhi implementasi budaya sekolah berwawasan lingkungan agar implementasi berjalan dengan lancar. Faktor pendukung adalah segala hal yang dapat membantu kelancaran dan keberhasilan terlaksananya kegiatan atau program. Sedangkan Faktor penghambat dalam suatu kegiatan implementasi adalah segala sesuatu yang menjadi kendala yang menghambat proses pelaksanaan kegiatan atau program (Pangestika, Malik, Shofwan, \& Siswanto, 2021).

Faktor pendukung yang dapat membantu kelancaran implementasi budaya sekolah berwawasan lingkungan dalam membentuk karakter peduli lingkungan diantaranya adalah sumber daya manusia dan sarana prasarana yang memadai, serta dukungan dari berbagai pihak yang dapat memunculkan semangat warga sekolah 
sehingga proses pelaksanaan budaya sekolah berwawasan lingkungan dapat berjalan dengan baik (Pelita \& Widodo, 2020). Kunci keberhasilan pembentukan karakter tidak hanya ditentukan oleh keterlibatan warga sekolah saja, melainkan juga ditentukan oleh adanya keterlibatan pihak luar sekolah seperti orang tua dan masyarakat (Arifin, 2017). Sedangkan faktor penghambat yang dapat menghambat implementasi budaya sekolah berwawasan lingkungan diantaranya adalah kurangnya anggaran dana untuk pelaksanaan kegiatan, kurangnya kepekaan warga sekolah terhadap lingkungan sekitar, serta kurangnya wawasan warga sekolah tentang lingkungan hidup (Pelita \& Widodo, 2020).

\section{PENUTUP}

Berdasarkan hasil penelitian, peneliti menyimpulkan bahwa budaya sekolah berwawasan lingkungan dalam membentuk karakter peduli lingkungan siswa di SDN temas 01 Batu diimplementasikan melalui 3 langkah yaitu perencanaan, pelaksanaan dan evaluasi. Kegiatan perencanaan adalah membentuk tim pengelola lingkungan di sekolah, membuat kajian lingkungan dan merencanakan aksi lingkungan. Kegiatan yang dilakukan saat pelaksanaan adalah membuat kebijakan berwawasan lingkungan, melaksanaakn kurikulum berbasis lingkungan, melaksanakan kegiatan lingkungan berbasis partisipatif, dan melakukan pengelolaan terhadap sarana prasarana pendukung ramah lingkungan di sekolah. Evaluasi dilakukan setiap bulan selama satu tahun. Tim pengelola lingkungan sekolah melakukan pemantauan terhadap keadaan kenekaragaman hayati di sekolah, tagihan listrik dan pengeluaran pembelian alat tulis kantor, menimbang jumlah sampah di sekolah dan memantau kemampuan siswa dalam mengelola lingungan baik dilihat dari aspek kognitif, afektif maupun psikomotorik. Faktor pendukung terlaksananya budaya sekolah berwawasan di SDN Temas 01 antara lain : (1) lokasi sekolah berada di kawasan yang masih asri dan jauh dari pabrik yang menimbulkan polusi udara; (2) banyaknya dukungan dari pihak luar kepada sekolah untuk melaksanakan budaya sekolah berwawasan lingkungan. Sedangkan faktor penghambatnya meliputi: (1) masih terbatasnya anggaran yang dialokasikan untuk penerapan budaya sekolah berwawasan lingkungan; (2) masih terdapat siswa yang kurang memiliki kesadaran dalam memilah sampah; (3) masih terdapat banyak sampah plastik di sekolah. Upaya sekolah dalam mengatasi hambatan yaitu melakukan (1) kerjasama sama dengan berbagai pihak dalam pengadaan sarana prarana ramah lingkungan di sekolah; (2) bekerjasama dengan orang tua siswa dalam pembiasaan di rumah dan memberikan peringatan atau sanksi bagi siswa yang tidak membuang sampah pada tempatnya dan tidak secara terpilah; (3) menerapkan $3 \mathrm{R}$ (Reduse, Reuse dan Recycle) untuk menanggulangi sampah plastik.

\section{UCAPAN TERIMA KASIH}

Terimakasih kepada seluruh warga SDN Temas 01 Batu yang telah berkontribusi dan meluangkan waktu untuk dapat memberikan informasi dan tanggapan terkait implementasi budaya sekolah berwawasan lingkungan dalam membentuk karakter peduli lingkungan siswa SDN Temas 01 Batu. Serta seluruh pihak yang tidak dapat disebutkan satu persatu dalam penelitian ini, sehingga penelitian ini dapat terlaksana dengan baik. 


\section{DAFTAR PUSTAKA}

Adawiyah, R. (2019). Implementation of Adiwiyata Program to Build Environmental Awareness. Journal of Wetlands Environmental Management, 7(2), 106-114.

Aini, M. H., Rachmadiarti, F., \& Prastiwi, M. S. (2014). Penguasaan Konsep dan Sikap Peduli Lingkungan Siswa SMA Adiwiyata Mandiri di Kabupaten Mojokerto. BioEdu, 3(3), 479-484.

Arifin, M. F. (2017). Model kerjasama Tripusat Pendidikan dalam Pendidikan Karakter Siswa. Muallimuna: Jurnal Madrasah Ibtidaiyah, 3(1), 78-86.

Caddafie, S. U., Martuti, N. K., \& Rudyatmi, E. (2017). The Impact of Adiwiyata Program On Environmental Caring Character. Journal of Biology Education, 6(3), 350-356.

Desfandi, M., Maryani, E., \& Disman. (2019). Implementation of Adiwiyata Program in The Effort to Create Environmental Cultured School in Banda Aceh. Sumatra Journal of Disaster, Geography and Geography Education, 3(2), 1-8.

Fadlilah, U., Ngabekti, S., \& Lisdiana. (2018). The Adiwiyata School's Role in the Development of Character Caring for the Environment (A Case Study at the Junior High School 6 Tuban). Journal of Innovative Science Education, 7(1), 5361.

Fatimah, \& Adawiyah, R. (2017). Sikap dan Perilaku Siswa Terhadap Keberadaan Sungai di Kota Banjarmasin. Jurnal Pendidikan Kewarganegaraan, 7(7), 37-45.

Isnaeni, Y. (2013). Implementasi Kebijakan Sekolah Peduli dan Berbudaya Lingkungan di SMP Negeri 3 Gresik. Jurnal Kebijakan dan Pengembangan Pendidikan, 1(2), 166-172.

Juraid, Hamzah, B., Mahpudz, A., \& Khaldun, R. I. (2019). Implementation And Development Of Adiwiyata Schools To Realize Character Of Students Care For Environment. International Journal of Scientific \& Technology Research, 8(10), 1226-1229.

Masturoh, \& Ridlo, S. (2020). Character Building of Environmental Care on Student In Sekolah Indonesia Kota Kinabalu (SIKK) Malaysia. Journal of Biology Education, 9(2), 193-201.

Miles, M., Huberman, A., \& Saldana, J. (2014). Qualitative Data Analysis A Methods Sourcebook. United States of Amerika: SAGE Publications.

Nada, H. N., Fajarningsih, R. U., \& Astirin, O. P. (2021). Adiwiyata (Green School) Program Optimization Strategy in Malang Regency to Realize Environmentally Friendly School Citizens. IJORER : International Journal of Recent Educational Research, 2(2), 121-137.

Pangestika, N., Malik, A., Shofwan, I., \& Siswanto, Y. (2021). Implementation of Character Education at Paud Sekolah Alam Ar Ridho Semarang. JournalNX- A Multidisciplinary Peer Reviewed Journal, 7(3), 191-204.

Pelita, A. C., \& Widodo, H. (2020). Evaluasi Program Sekolah Adiwiyata di Sekolah Dasar Muhammadiyah Bantul Kota. Sekolah Dasar: Kajian Teori dan Praktik Pendidikan, 29(2), 145-157.

Permana , B. I., \& Ulfatin, N. (2018). Budaya Sekolah Berwawasan Lingkungan pada Sekolah Adiwiyata Mandiri. Ilmu Pendidikan: Jurnal Kajian Teori dan Praktik Kependidikan, 3(1), 11-21.

Pradini, I. K., Sujanto, B., \& Nurjannah. (2018). Implementasi Program Sekolah Adiwiyata dalam Peningkatan Mutu Pendidikan di SDN Tanah Tinggi 3 Kota 
Tangerang. JGG- Jurnal Green Growth dan Manajemen Lingkungan, 7(2), 122132.

Priambodo, P., Aslamiah, \& Rizalie, M. (2021). Implementation of the Adiwiyata School Program Through Participatory Based Environmental Activities (Multisite Study at Banjarmasin 29 Public Middle School and Banjarmasin 8 Public Middle School). Journal of K6 Education and Management, 4(1), 23-36.

Purwanti, D. (2017). Pendidikan Karakter Peduli Lingkungan dan Implementasinya. DWIJACENDEKIA Jurnal Riset Pedagogik, 1(2), 14-20.

Riki, M., \& Sumarnie. (2021). Manajemen Program Adiwiyata di SMP Negeri 1 Mentaya Hilir Selatan Kabupaten Kotawaringin Timur. Equity in Education Journal (EEJ), 3(1), 47-53.

Rokhmah, U. N. (2019). Pelaksanaan Program Adiwiyata Sebagai Upaya Pembentukan Karakter Peduli Lingkungan Siswa Di Madrasah Ibtidaiyah. Al Qalam: Jurnal Ilmiah Keagamaan dan Kemasyarakatan, 13(1), 67-68.

Sukmadita, N. S. (2013). Metode Penelitian Pendidikan. Bandung: PT Remaja Rosdakarya .

Tresnani, L. D. (2020). Penanaman Karakter Peduli Lingkungan melalui Kegiatan. $A L$ HIKMAH : Jurnal Pendidikan dan Pendidikan Agama Islam, 3(1), 11-17.

Wardani, D. N. (2020). Analisis Implementasi Program Adiwiyata dalam Membangun Karakter Peduli Lingkungan (Studi Kasus Di MIN 1 Ponorogo). Southeast Asian Journal of Islamic Education Management, 1(1), 60-73.

Zafi, A. (2018). Transformasi Budaya Melalui Lembaga Pendidikan (Pembudayaan dalam Pembentukan Karakter). Al-Ghazali, 1(1), 1-16. 